\section{DO PATHOLOGISTS USE THE ELECTRON MICROSCOPE ENOUGH?}

Stephen W. Carmichael, ${ }^{1}$ Mayo Clinic

The compound light microscope has been used by pathologists for centuries, and remains the common tool for making a diagnosis. A half century ago, the electron microscope (EM) was introduced, and has also been proven to be a valuable, but expensive, tool. In the meantime, other tools and methods have worked their way into the pathologists' armamentarium, with immunohistochemical, genetic, and molecular techniques being the most obvious examples. Josep Lloreta-Trull, Lola Ferrer, Teresa Ribalta, Marco Pavesi, and Sergio Serrano examined the literature to determine the frequency and appropriateness with which pathologists use the EM in their studies.

Whereas EM is a basic tool in morphologic research, throughput limitations and/or budgetary constraints limit its routine use in pathologic diagnosis. Lloreta-Trull et al. were concerned that these restrictions have been limiting the optimal use of the EM in the practice of pathology. They examined all of the articles in three leading pathology journals over a five-year period. This amounted to 2,531 articles! Studies were classified by subject and divided into three main categories: case reports, descriptive articles, or new diagnostic strategies. Of these, $17.6 \%$ (448) used EM and were the subject of the study. Both the actual and potential EM content were scored as follows: 0 , none; 1 , illustrative; 2 , supportive; 3 , confirmative (gold standard); 4, extensive; and 5, predominant. Using this scale, $77 \%$ were deemed to contain relevant ultrastructural information. The selected articles dealt mostly with soft tissue tumors, followed by genitourinary and nervous system diseases. Analysis showed that EM support was lacking most often in articles on serosal neoplasms and on new diagnostic strategies (e.g., novel combinations of antibodies), followed by muscle diseases, head and neck tumors, and gynecologic pathology. It was suggested that the remaining $23 \%$ could benefit from including EM as an ancillary, control or gold standard method to complement, support, or confirm the results. Lloreta-Trull et al. also looked at trends toward increasing or decreasing the use of EM over the five-year period, and no definite trends were found in either direction.

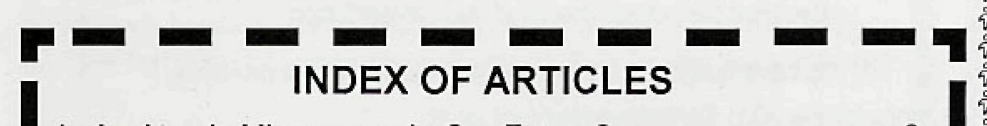

Is An Atomic Microscope In Our Future?. Stephen W. Carmichael, Mayo Clinic

Nanomechanical Probing With Scanning Force Microscopy ....8 V.V. Tsukruk \& V.V. Gorbunov, lowa State University

Why Is My House So Dirty?... James J. Benko, Microspec Analytical

Recycling Osmium Tetroxide John A. Kiernan, The University of Western Ontario

Wrinkle-Free Brain Sections. Connie McManus, Utah State University

How Good Is Your Glut?. Bob Compton, Microscopy Today

Why Pressure Scales Cause So Much Confusion Anthony D. Buonaquisti, University of South Florida

Rotary Shadowing Macromolecules. Douglas R. Keene, Shriners Hospital Research Facilities

Lloreta-Trull et al. demonstrated that authors include ultrastructural data relatively often in their reports, which may come as a surprise to many pathologists. However, a small but nonnegligible percentage of pathology articles could benefit from including EM as an ancillary, control, or gold standard method to complement, support, or confirm their results. Of course, the tools that pathologists use for a published study may not reflect tools used in everyday practice, but the conclusions of this retrospective study of the literature is nevertheless informative. It was pointed out that an EM in every hospital is not justified, but academic institutions that teach students and residents and are involved in basic research should be equipped with an EM facility. This facility, in turn, could support diagnostic activity from that institution, and from referring hospitals.

1. The author gratefully acknowledges Dr. Josep Lloreta-Trull for reviewing this article.

2. Lloreta-Trull, J., L. Ferrer, T. Ribalta, M. Pavesi, and S. Serrano, electron microscopy in pathology articles: A retrospective appraisal, Ultrastructural Path. 24:105-108, 2000.

3. American Joumal of Surgical Pathology, Human Pathology, and Modern Pathology

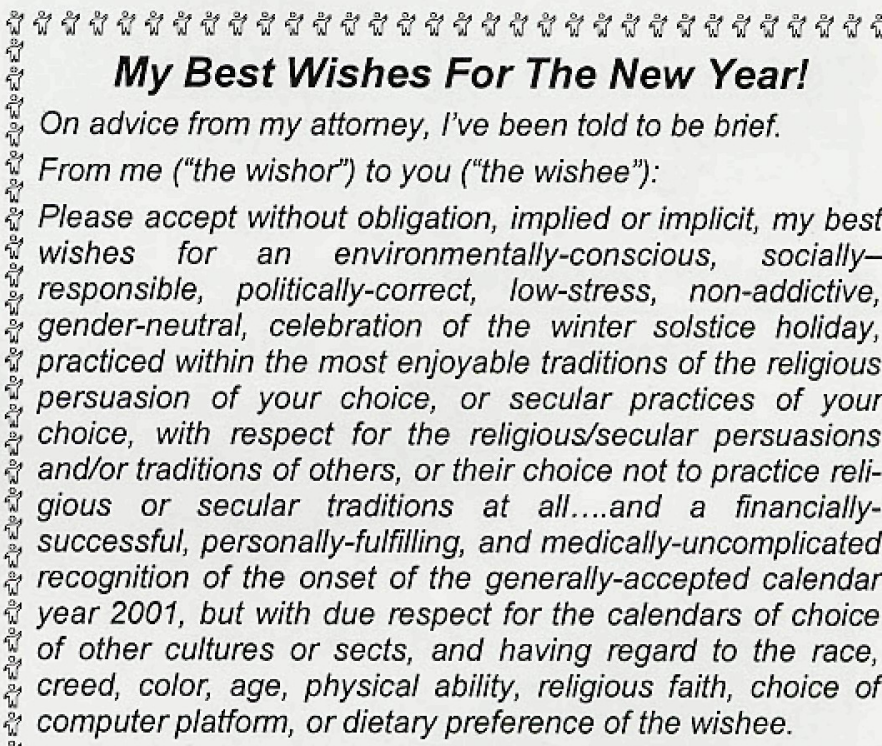
By accepting this greeting you are bound by these terms that:

$\leq$ This greeting is subject to further clarification or withdrawal:

$\leq \quad$ This greeting is freely transferable provided that no alteration shall be made to the original greeting and that the proprietary rights of the wishor are acknowledged;

$\leq \quad$ This greeting implies no promise by the wishor to actually implement any of the wishes;

$\leq$ This greeting may not be enforceable in certain jurisdictions and/or the restrictions herein may not be binding upon certain wishes in certain jurisdictions and is revocable at the sole discretion of the wishor:

$\leq$ This greeting is warranted to perform as reasonable may be expected within the usual applications of good tidings, for a period of one year or until the issuance of a subsequent holiday greeting, whichever comes first;

$\leq$ And the wishor warrants this greeting only for the limited replacement of this wish or issuance of a new wish at the sole discretion of the wishor.

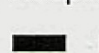




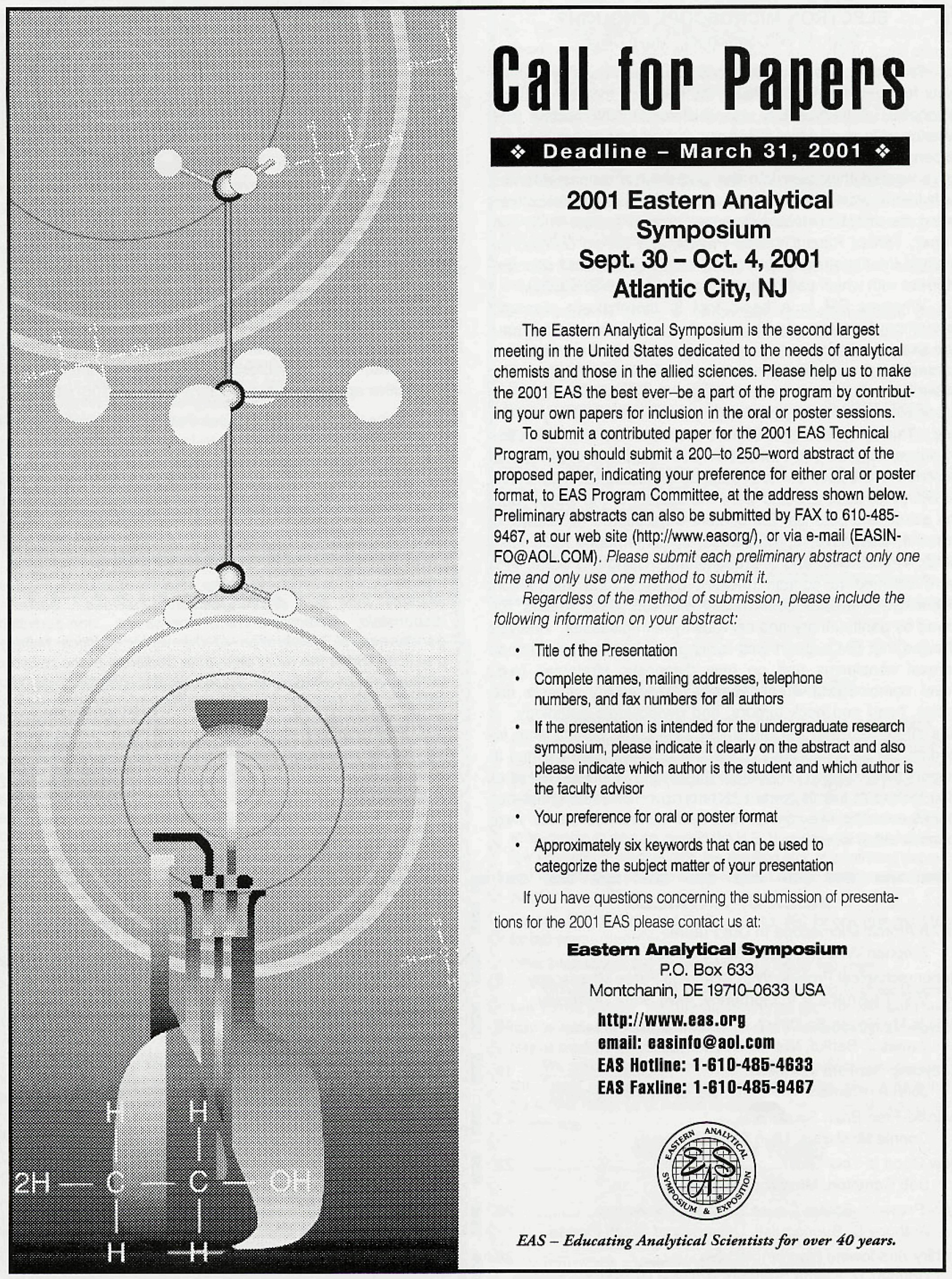




\section{$\Rightarrow$ Electron Microscopy Short Course}

Electron Microscopy \& Microanalysis is a one-day short course that will be held Sunday, March 4 at PITTCON 2001 in New Orleans. The course is designed as an introduction to scanning electron microscopy, transmission electron microscopy and $\mathrm{x}$-ray microanalysis for industrial analytical chemists. Numerous examples of the use of electron microscopy in materials analysis are presented. For further information visit the PITTCON 2001 web site, www.pittcon.org, or contact the instructor, Dr. Mark Germani, MicroMaterials Research, 136 Shore Drive, Suite 200, Burr Ridge, IL 60521. Phone (630) 3258170 , fax (630) $325-8178$ or e-mail: mgermani@micromaterialsresearch.com

\section{$\Rightarrow$ Analytical Chemistry Starter Grant Award}

The Society for Analytical Chemists of Pittsburgh will award one grant of $\$ 20,000$ to an assistant professor in the field of analytical chemistry. The purpose of this grant is to encourage high-quality, innovative research by a new analytical chemistry professor and to promote the training and development of graduate stidemts in this field. Assistant professors whko have accepted a United States college or universtiy appointment since December 31, 1997 are eligible.

Completed applications must be received by February 28 , 2001. For applications and further information, contact: Janeth Pifer, (800)825-3221 Ext. 204

\section{Modern Coating Solutions for Today's EM Sample Prep Needs}

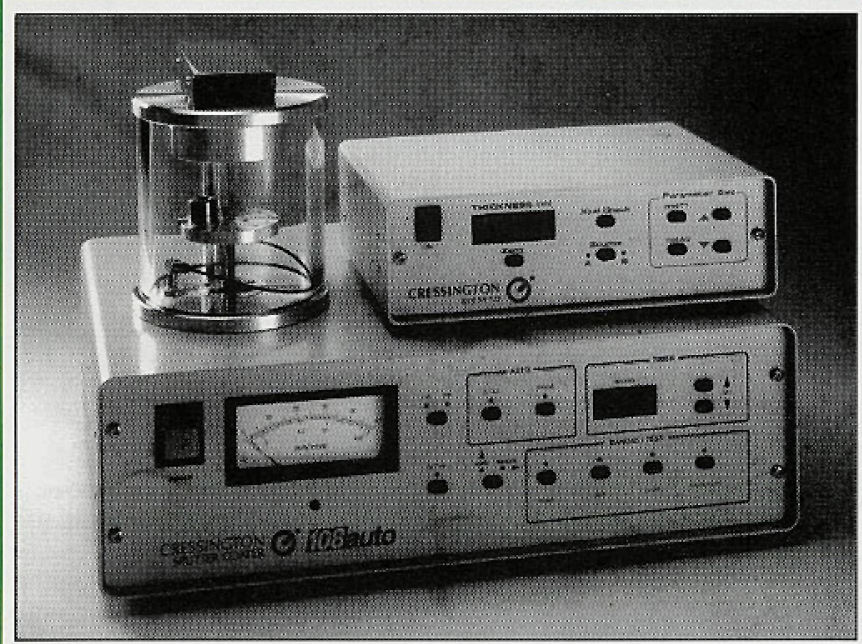

Compact modern desktop systems with fast cycle times. Carbon and sputtering systems for all SEM, FE-SEM and TEM applications.

\section{CRESSINGTON}

Cressington Scientific Instruments, Inc.

508 Thomson Park Drive, Cranberry Twp., PA 16066

TEL 800-755-1781 / 724-772-0220 FAX 724-772-0219

Website: www.cressington.com

\section{$\Rightarrow$ 3rd Party Service Providers}

A list of 3rd Party Service Providers has been compiled by Ron Veil and is available on Gary Gaugler's web site as follows: http://gaugler.com/EMservice.xis (use exact case).

\section{$\Rightarrow$ Updated Monthly Microscopy Listserver} Archives and Serach Engine:

www.msa.microscopy.com/MicroscopyListserver/ Microscopy/Archives.html

\section{NIKON Puts World's Largest Archives Of Award-Winning Photomicrographs Online Microscope images available for editorial/educational purposes.}

The world's largest archives of prize-winning photographs captured through microscopes is now available online at www. microscopyu.com and www.nikonusa.com. The entire gallery of photographs, all honorees in the Nikon International Small World Photomicrography Competition over the past 26 years, can be viewed online, and may be procured free of charge for editorial, educational and non-profit purposes.

The nearly 500 images in the gallery reflect the invisible universe beneath the lens of a light microscope in all its extraordinary wonder and diversity. The brilliantly hued winners represent subjects that range for cancer cells, deer ticks, bones depleted by osteoporosis, and cell division, all the way to integrated circuit chips, pharmaceuticals, currency, textiles, diatoms, crystals, vitamins and more. Even common household objects like detergent, aspirin, sugar, bleach, tears, orange peels and potato chips are represented among the winners.

The competition is open to anyone with an interest in photography through the microscope. Truly international in scope, entries have been received from the U.S., Canada, Mexico, Europe, Australia, Latin America, Asia and Africa. Winners have come from such fields as chemistry, biology, materials research, botany, biotechnology, and pharmaceuticals; hobbyists also have entered and won. All entries are due by Nikon by June 30 .

For more information on the competition, to view the entire gallery of past Small World Competition winners, or to download Small World Competition entry forms, visit: www. microscopyu.com or www.nikonusa.com

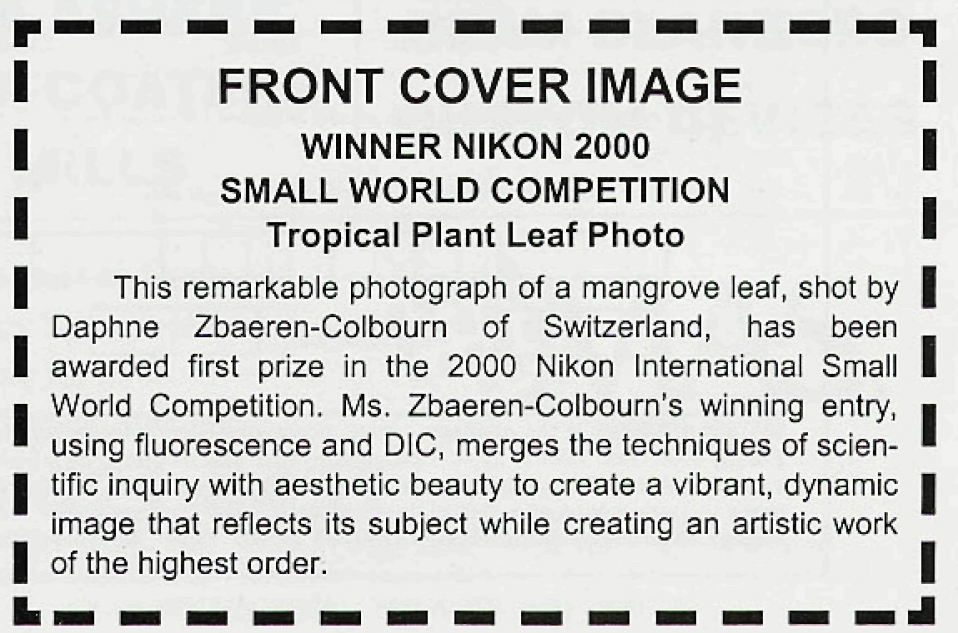




\section{journal of electron microscopy}

Now Full-Text Online FREE to subscribers.

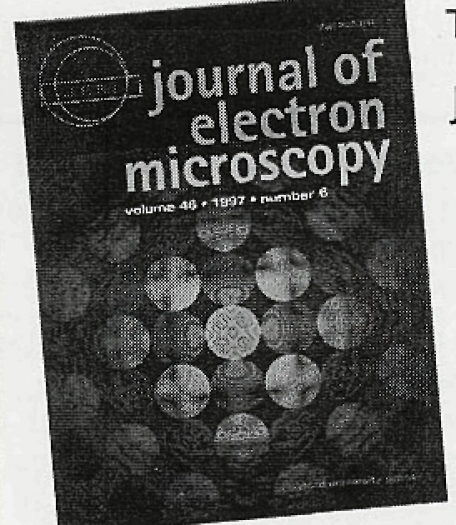

The Journal of Electron Microscopy is the official journal of the Japanese Society of Electron Microscopy, the second largest society

of electron microscopy in the world. JEM is an international forum open to all scientists in the field for publishing the best research in advanced electron microscopy and new scanning probe microscopy. To ensure this, JEM has appointed a truly international editorial board. Now, if you or your library

subscribe, you can access the journal full-text online from your desktop.

Sign up today for the FreE e-mail table of contents service. Plus — search abstracts and more on our website.

\section{www.jmicro.oupjournals.org}

\section{Subscribe to the Journal of Electron Microscopy today! \\ 6 issues, Volume 50, 2001 ISSN 0022-0744}

Annual Rate: $\$ 335 / £ 210$

MSA/RMS/ASEM/BMS MEMBERS \$125/£80

Please note $£$ Sterling rates apply in Europe, US\$ rates elsewhere.

\section{Name \\ Address}

City State ZipCode Country

Phone

Payment is enclosed (check made payable to Oxford University Press).

$\square$ Please bill me.

Please charge my Mastercard/Visa/AmEx/Diners (circle one).

Start Date

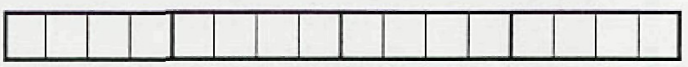

Expiration Date

Signature

RETURN ADDRESS: In the Americas, please return your order form to: Journals Marketing, Oxford University PTess, 2001 Evans Road, Cary, NC 27513, USA. Fax: 919677 1714. Subscriptions may also be placed by telephone using any major credit card. Please call Journals Customer Service at 18008527323 (USA and Canada only) or 9196770977 (outside USA and Canada). E-mail: jniorders@oup-usa.org Elsewhere, please return to: Journals Marketing, Oxford University Press, Great Clarendon Street, Oxford OX2 6DP, UK Fax: $+44(0) 1865267835$. Or call the Journals Subscription Department at +44 (0)1865 267907. E-mail: jnl.orders@oup.co.uk 


\section{Oominns avenins}

YEAR 2001 McCRONE RESEARCH INSTITUTE SCHEDULE:

$\checkmark$ April 9/13: Advanced FTIR Microscopy

$\checkmark$ April 16/20: Electronic Imaging

$\checkmark$ April 23/27: Scanning Electron Microscopy

$\checkmark$ May 30/June 1: Fluorescence Microscopy

$\checkmark$ Sept. 5/7: Microtomy

$\checkmark$ Sept. 10/14: Advanced FTIR Microscopy

$\checkmark$ Sept. 24/26: Caking of Crystals

$\checkmark$ Nov. 5/9: Particle Isolation, Manipulation and mounting for Additional Analysis

$\checkmark$ Nov. 12/16: Scanning Electron Microscopy

For further information, contact Ms. Nancy Daerr: (312)842-7100, Fax: (312)842-1078, eMail: ndaerr@mcri.org

$\checkmark$ February 25/28 '01: Contact Mechanics in Adhesion Science (The Adhesion Society) Williamsburg, VA, www. adhesionsociety.org/

$\checkmark$ March 4/9 '01: PITTCON 2001, New Orleans, LA. www.pittcon. org $\checkmark$ March 25/29 01: 12th International Confere nce on Microscopy of Semiconducting Materials (Royal Microscopical Society) University of Oxford, UK, http://www.rms.org.uk/currentevents2.htm\#MSMXII

$\checkmark$ April 1/4 '01: Focus On Microscopy 2001, University of Amsterdam, The Netherlands. www.focusonmicroscspy. org/

$\checkmark$ April 1/5 '01: Inter- and Intra-Molecular Forces in Biological Sciences (Amecical Chemical Society) San Diego CA, Prof. Jan Hoh: (410)614-3795

$\checkmark$ May 5/7 '01: SCANNING 2001: (FAMS) New York City. Paula Pivnick : (201)818-1010, scanning@fams.org

$\checkmark$ May 6/10 01: Modern Developments and Applications in Microbeam Analysis (EMAS), Tampere, Finland, www.emas.ac.ukJ

$\checkmark$ May 10/18 01: Analytical \& Quantitative Light Microscopy Marine Biological Laboratory) Woods Hole, MA. (508)289-7401

$\checkmark$ May 13/16 '01: Food Structure \& Functionality Symposium 2001, Minneapolis, MN. eMail: meeting@AOCS.org

$\checkmark$ May 21/25 '01: FE-SEM and Image Analysis Courses Montreal, Canada. Dr. Pierre Hovington: (450)652-8125, eMail: hovington. pierre@ireq.ca

$\checkmark$ May 22/29 "01: Microinjection Techniques In Cell Biology (Marine Biological Laboratory) Woods Hole, MA. (508)289-7401

$\checkmark$ June 6/8 01: Microscopical Society of Canada Annual Meeting Fredericton, New Brunswick, Canada, http://www.unb.ca/msc2001

\section{LEHIGH MICROSCOPY SCHOOL}

$\checkmark$ June 11/15 '01: SEM and X-ray Microanalysis

$\checkmark$ June 10, '01: Introduction to SEM and EDS

$\checkmark$ June 18/22 101: Advanced Scanning Electron Microscopy Quantitative X-ray Microanalysis

$\checkmark$ June 18/21 101: Analytical Transmission Electron Microscopy

$\checkmark$ June 19/21 01: TEM Specimen Preparation

$\checkmark$ June 19/22 01: Atomic Force Microscopy

For further information, contact Ms. Sharon Coe at: tel.: (610)7585133, fax: (610)758-4244, eMail: sharon.coe@lehigh.edu

$\checkmark$ June 18/21 '01: 17th Annual Short Course on Molecular Microspectroscopy (Miami University) Oxford OH. (513)529-2874

$\checkmark$ July 2/6 '01: 16th International Conference on $X$-ray Optics and Microanalysis (ICXOM XVI), Vienna, Austria, www.icxom.at

$\checkmark$ August 5/9 '01: Microscopy \& Microanalysis 2001 (MSA/MAS) Long Beach CA, Mary Rebedeau: msa@tradeshownet.com

$\checkmark$ August 30/Sept 9 '01: Practical Course on Electron Microscopy Immunocytochemistry and Stereology for Cell Biology (EMBL) Heidelberg, Germany

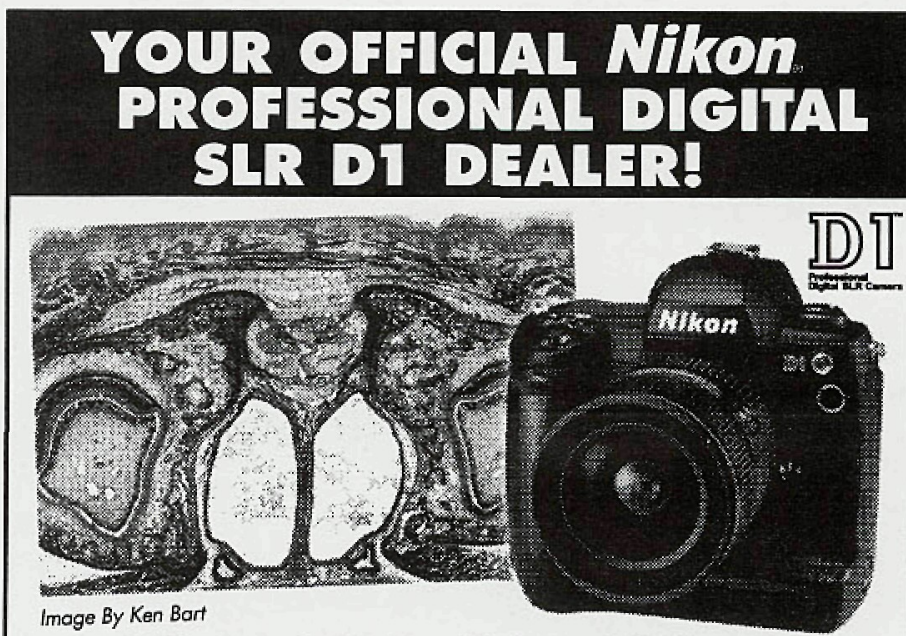

2.74-megapixel - Superhigh-speed, high-quality

4.5 frames per second - 3D Digital Matrix Image Control

High-speed AF system including Dynamic AF operation

3D Multi-Sensor Balanced Fill-Flash for D1

Compatible with virtually any F-mount Nikkor lens

$\$ 4,999$ Nikon DI Digital SIR Camera Set: DI Comera Body, EN-4 Baftery Pock

MH-16 Quick Charger, Video Cable, Nikon View DX Browser, Nikon Video Cable for DI

DI Neck Strap, Instruction Manual, Nikon Limited One Year Warranty Document. "LENS SOD SEPARATELY

\section{Nikon.}

We take the word:
greates pitures:
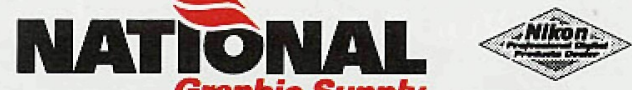
Graphic Supply

\subsection{0 .223 .7130 ext.3109}

226 North Allen Street, Albany, New York 12206 - Fax 800-832-2205 www.ngscorp.com - E-mail: seisales $\mathbb{Q}$ ingscorp.com

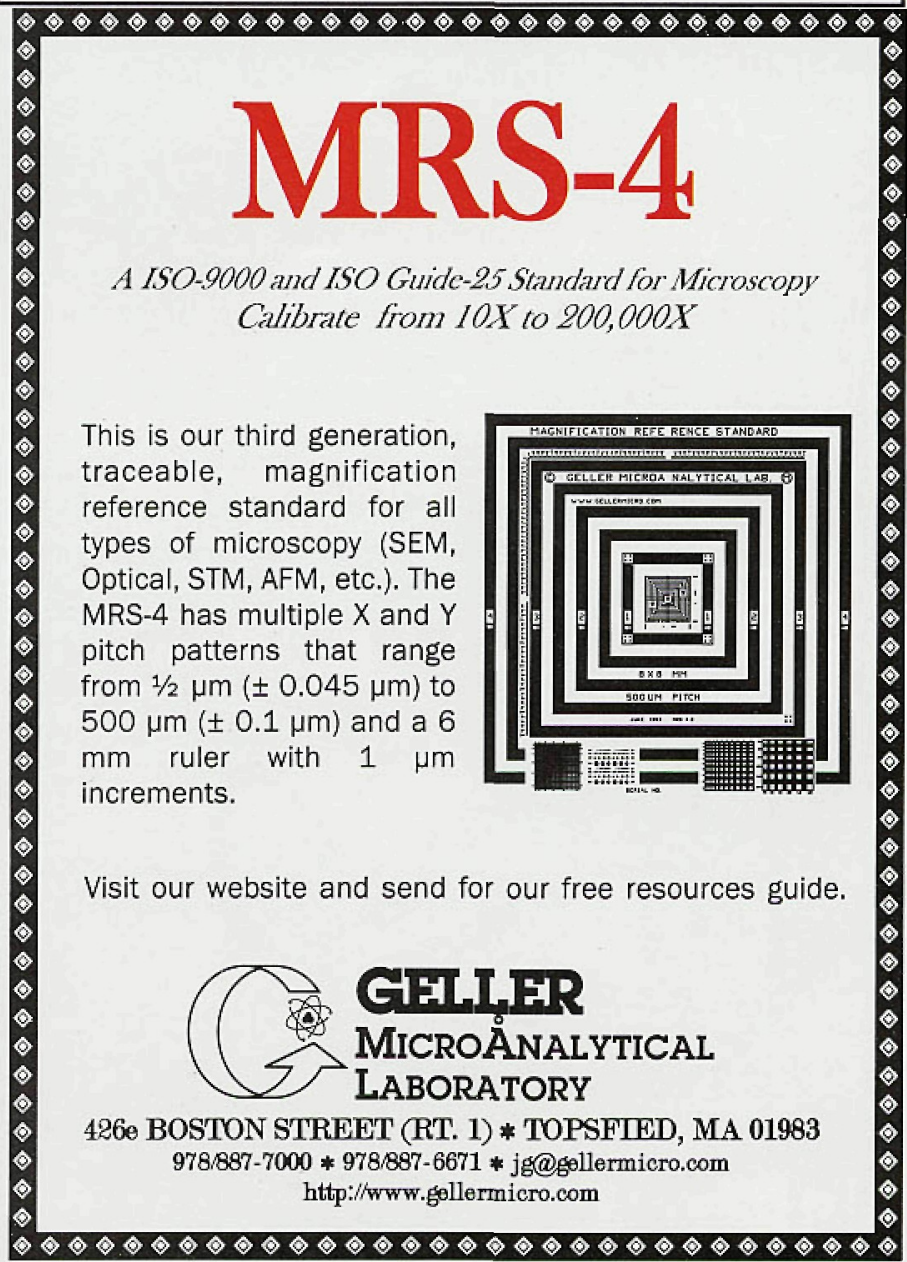

